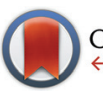

CrossMark < click for updates

Cite this: Org. Chem. Front., 2016, 3, 1514

Received 1st August 2016,

Accepted 8th September 2016

DOI: $10.1039 / \mathrm{c} 6 q 000423 \mathrm{~g}$

rsc.li/frontiers-organic

\section{Gold-catalyzed cycloisomerization of trifluoromethylated allenols: sustainability and mechanistic studies $\uparrow$ :}

\author{
Linda Lempke, Hülya Sak, Michael Kubicki and Norbert Krause* \\ Trifluoromethyl-substituted $\alpha$-allenols are cyclized to the corresponding 2,5-dihydrofurans in the \\ presence of neutral or cationic gold catalysts. The catalyst can be recycled if ionic liquids (in particular \\ [BMIM][PF 6$]$ ) are used as reaction medium. The allene forms droplets in the ionic liquid generating a \\ heterogeneous two-phasic system. Kinetic studies in organic solvents using electronically different gold \\ catalysts allowed to identify the protodeauration of a $\sigma$-gold-species as rate-determining step of typical \\ allene cyclizations. Only if a $\mathrm{CF}_{3}$ group is present at $\mathrm{C}-5, \pi$-complex formation is rate-limiting.
}

\section{Introduction}

The importance of fluorinated substances is reflected in a wide range of applications in academia and industry. ${ }^{1}$ Numerous reports concentrate on selective fluorinations and the introduction of fluorinated substituents, emphasizing the rising interest in fluoroorganic chemistry. ${ }^{2}$ The dramatic influence of fluorine or fluorinated substituents on molecular properties renders them indispensable for the modulation of acidity, metabolic stability, lipophilicity, solubility, bioavailability, and binding affinity to target proteins. ${ }^{3}$

In homogeneous gold catalysis, various methods are available for the formation of carbon-fluorine bonds. ${ }^{4}$ Frequently, these involve the use of electrophilic fluorinating agents like Selectfluor ${ }^{5}{ }^{5}$ There is also a limited number of studies on gold-catalyzed transformations of fluorinated substrates which afford fluorine-tagged heterocycles. ${ }^{5 a, 6}$ Based on our experience in the gold-catalyzed activation of unsaturated molecules (mostly allenes) for regio- and stereoselective cyclization reactions, ${ }^{7}$ we now present the first results of a study on the effect of trifluoromethyl substituents on the cyclization of $\alpha$-hydroxyallenes to 2,5-dihydrofurans. Main objectives of these investigations are the synthesis of fluorinated heterocycles under sustainable reaction conditions employing recyclable gold catalysts ${ }^{7 d, 8,9}$ in ionic liquids $(\mathrm{ILS})^{9}$ as reaction medium, as well as, an improved mechanistic understanding of these transformations with the aid of kinetic studies.

Dortmund University of Technology, Organic Chemistry, Otto-Hahn-Strasse 6, D-44227 Dortmund, Germany. E-mail: norbert.krause@tu-dortmund.de $\dagger$ Dedicated to Prof. Barry M. Trost on the occasion of his $75^{\text {th }}$ birthday. \$Electronic supplementary information (ESI) available: Experimental details and supporting characterization data. See DOI: 10.1039/c6qo00423g

\section{Results}

\section{Synthetic procedures}

For a systematic study of the influence of trifluoromethyl substituents on the reactivity in the gold-catalyzed cycloisomerization, three regioisomeric $\alpha$-hydroxyallenes $1 \mathbf{1 a}-\mathbf{c}$ were synthesized (see ESI: for details). For the first part of these investigations, the imidazolium-based ILs and gold catalysts shown in Scheme 1 were used.

The optimization of the reaction conditions was carried out with allene 1a. Different ILs were tested in the presence of $5 \mathrm{~mol}^{2} \mathrm{AuCl}_{3}$ as catalyst (Table 1). Similar to earlier studies, ${ }^{9}$ [BMIM $]\left[\mathrm{PF}_{6}\right]$ gave the shortest reaction time of $4 \mathrm{~h}$ (entry 1), while the cyclization in [EMIM] $\left[\mathrm{PF}_{6}\right]$ is much slower (entry 2). The ionic liquids $[\mathrm{EMIM}]\left[\mathrm{HSO}_{4}\right]$ and $[\mathrm{BMIM}]\left[\mathrm{HSO}_{4}\right]$ were used at $60{ }^{\circ} \mathrm{C}$ to decrease their viscosity. In this manner, complete conversions were observed after 1-1.5 h (entries 4 \& 5). When $[\mathrm{BMIM}]\left[\mathrm{PF}_{6}\right]$ was used at the same temperature, complete consumption of the starting material was detected already after 15 min (entry 3). To rule out the possibility of an acidcatalyzed cyclization ${ }^{10}$ in the presence of $[\mathrm{EMIM}]\left[\mathrm{HSO}_{4}\right]$ and $[\mathrm{BMIM}]\left[\mathrm{HSO}_{4}\right]$, the reactions were repeated in the absence of a gold catalyst. No conversion was observed after $24 \mathrm{~h}$ (entries 6

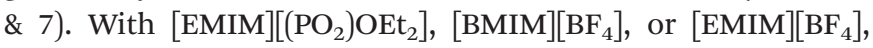
unsatisfactory results were obtained (entries $8-10$ ). The high reactivity observed in $[\mathrm{BMIM}]\left[\mathrm{PF}_{6}\right]$ may be due to formation of $\mathrm{L}-\mathrm{Au}-\mathrm{OPOF}_{2}$ species by fluoride abstraction or hydrolysis of $\mathrm{PF}^{-}$by adventitious water. ${ }^{11}$

Next, we investigated the reactivity of allenol $\mathbf{1 a}$ in $[\mathrm{BMIM}]\left[\mathrm{PF}_{6}\right]$ in the presence of different gold catalysts at room temperature (Table 2). Compared to $\mathrm{AuCl}_{3}$, the activity of $\mathrm{AuBr}_{3}$ is much lower (entry 2 vs. 1). In contrast to this, cationic gold(I) complexes afforded full conversion of $\mathbf{1 a}$ with only 

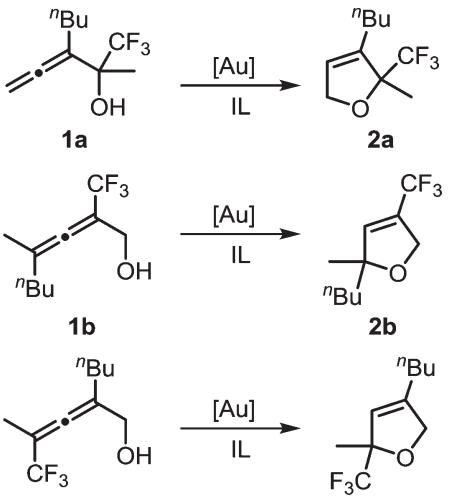

$1 \mathrm{c}$

2c
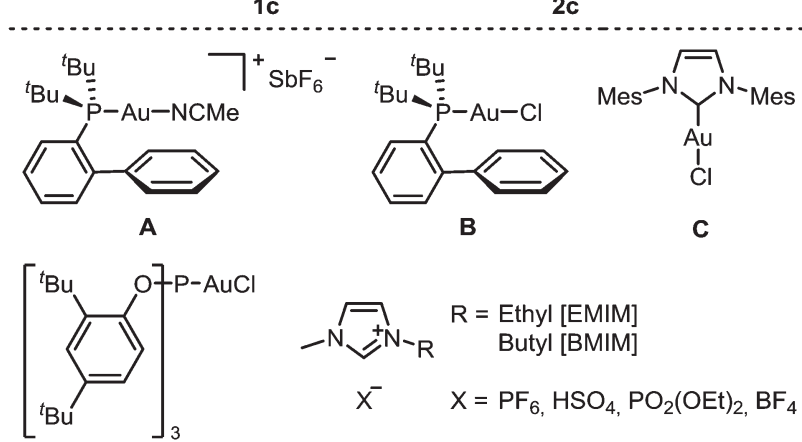

$\mathrm{R}=$ Ethyl [EMIM]
Butyl [BMIM]

$\mathrm{X}^{-} \quad \mathrm{X}=\mathrm{PF}_{6}, \mathrm{HSO}_{4}, \mathrm{PO}_{2}(\mathrm{OEt})_{2}, \mathrm{BF}_{4}$

D

Scheme 1 Gold-catalyzed cycloisomerization of trifluoromethylated allenes $1 \mathrm{a}-\mathrm{c}$ using gold catalysts $\mathrm{A}-\mathrm{D}$ and imidazolium-based ionic liquids as solvent.

Table 1 Influence of the ionic liquid on the gold-catalyzed cycloisomerization of $\alpha$-hydroxyallene $1 \mathrm{a}$ to dihydrofuran $2 \mathrm{a}^{\mathrm{a}}$

\begin{tabular}{llllc}
\hline Entry & IL & $T\left[{ }^{\circ} \mathrm{C}\right]$ & Time & Conv. $^{b}[\%]$ \\
\hline 1 & {$[\mathrm{BMIM}]\left[\mathrm{PF}_{6}\right]$} & 25 & $4 \mathrm{~h}$ & 100 \\
2 & {$[\mathrm{EMIM}]\left[\mathrm{PF}_{6}\right]$} & 25 & $24 \mathrm{~h}$ & $14^{d}$ \\
3 & {$\left[{\mathrm{BMIM}]\left[\mathrm{PF}_{6}\right]}\right.$} & 60 & $15 \mathrm{~min}$ & 100 \\
4 & {$[\mathrm{BMIM}]\left[\mathrm{HSO}_{4}\right]$} & 60 & $1 \mathrm{~h}$ & 100 \\
5 & {$[\mathrm{EMIM}]\left[\mathrm{HSO}_{4}\right]$} & 60 & $1.5 \mathrm{~h}$ & 100 \\
6 & {$[\mathrm{BMIM}]\left[\mathrm{HSO}_{4}\right]^{c}$} & 60 & $24 \mathrm{~h}$ & $0^{d}$ \\
7 & {$[\mathrm{EMIM}]\left[\mathrm{HSO}_{4}\right]^{c}$} & 60 & $24 \mathrm{~h}$ & $0^{d}$ \\
8 & $\left.[\mathrm{EMIM}]\left[\mathrm{PO}_{2}\right) \mathrm{OEt}_{2}\right]$ & 25 & $5 \mathrm{~d}$ & $9^{d}$ \\
9 & {$[\mathrm{BMIM}]\left[\mathrm{BF}_{4}\right]$} & 25 & $24 \mathrm{~h}$ & $30^{d}$ \\
10 & {$[\mathrm{EMIM}]\left[\mathrm{BF}_{4}\right]$} & 25 & $24 \mathrm{~h}$ & $0^{d}$
\end{tabular}

${ }^{a}$ Catalyst: $\mathrm{AuCl}_{3}$ (5 mol\%). ${ }^{b}$ Determined by GC-FID. ${ }^{c}$ Reaction carried out without gold catalyst. ${ }^{d}$ Allene 1 a was reisolated.

$2 \mathrm{~mol} \%$ catalyst loading (entries 3-8). The highest activity was found with catalyst A which required only 15 min for complete conversion (entry 4). In the case of neutral chlorogold(I) complexes $\mathbf{B}, \mathbf{C}, \mathbf{D}$, and $\mathrm{Ph}_{3} \mathrm{PAuCl}$, addition of $\mathrm{AgSbF}_{6}$ is mandatory for formation of the active cationic catalyst which gave reaction times of 1-6 $\mathrm{h}$ (entries 5-8). Without the silver additive no reaction takes place. $\mathrm{AgSbF}_{6}$ itself is a less reactive catalyst, leading to $25 \%$ conversion after $3 \mathrm{~d}$ (entry 9).

After optimization of the reaction conditions, we determined reactivity profiles of the regioisomeric trifluoromethylsubstituted $\alpha$-hydroxyallenes $1 \mathrm{a}-\mathbf{c}$ in $[\mathrm{BMIM}]\left[\mathrm{PF}_{6}\right]$ at room
Table 2 Influence of the gold catalyst on the cycloisomerization of $\alpha$-hydroxyallene $1 \mathrm{a}$ to dihydrofuran $2 \mathrm{a}$ in $[\mathrm{BMIM}]\left[\mathrm{PF}_{6}\right]^{a}$

\begin{tabular}{llllc}
\hline Entry & Catalyst & mol\% & Time & Conv. $^{b}[\%]$ \\
\hline 1 & $\mathrm{AuCl}_{3}$ & 5 & $4 \mathrm{~h}$ & 100 \\
2 & $\mathrm{AuBr}_{3}$ & 5 & $24 \mathrm{~h}$ & $10^{c}$ \\
3 & $\mathrm{Ph}_{3} \mathrm{PAuNTf}_{2}$ & 2 & $1.5 \mathrm{~h}$ & 100 \\
4 & $\mathbf{A}$ & 2 & $15 \mathrm{~min}$ & 100 \\
5 & $\mathbf{B} / \mathrm{AgSbF}_{6}$ & 2 & $1 \mathrm{~h}$ & 100 \\
6 & ${\mathrm{C} / \mathrm{AgSbF}_{6}}_{7}$ & 2 & $5 \mathrm{~h}$ & 100 \\
8 & $\mathbf{D} / \mathrm{AgSbF}_{6}$ & 2 & $6 \mathrm{~h}$ & 100 \\
9 & $\mathrm{Ph}_{3} \mathrm{PAuCl} / \mathrm{AgSbF}_{6}$ & 2 & $4 \mathrm{~h}$ & 100 \\
& $\mathrm{AgSbF}_{6}$ & 2 & $3 \mathrm{~d}$ & $25^{c}$
\end{tabular}

${ }^{a}$ At room temperature. ${ }^{b}$ Determined by GC-FID. ${ }^{c}$ Allene 1a was reisolated.

Table 3 Reactivity of $\alpha$-hydroxyallenes $1 \mathrm{a}-\mathrm{c}$ towards different gold catalysts in $\left[\mathrm{BMIM]}\left[\mathrm{PF}_{6}\right]^{a}\right.$

\begin{tabular}{|c|c|c|c|c|}
\hline Entry & $\begin{array}{l}\text { Allene: } \\
{[\mathrm{Au}]}\end{array}$ & $\begin{array}{l}\mathbf{1 a} \\
\mathbf{1 a}\left[\text { Time } \mathrm{h}^{-1}\right]\end{array}$ & $\begin{array}{l}\mathbf{1 b} \\
\mathbf{1 b}\left[\text { Time } \mathrm{h}^{-1}\right]\end{array}$ & $\begin{array}{l}\text { 1c } \\
\text { 1c }\left[\text { Time } h^{-1}\right]\end{array}$ \\
\hline 1 & $\mathrm{AuCl}_{3}{ }^{b}$ & 4 & $24^{c}$ & $24^{d}$ \\
\hline 2 & A & 0.25 & 4 & 1 \\
\hline 3 & $\mathrm{Ph}_{3} \mathrm{PAuNTf}_{2}$ & 1.5 & 6 & 2.5 \\
\hline 4 & $\mathrm{D} / \mathrm{AgSbF}_{6}$ & 6 & $24^{e}$ & 24 \\
\hline
\end{tabular}

${ }^{a}$ Time required for full conversion (or conversion after $24 \mathrm{~h}$ ) at room temperature with $2 \mathrm{~mol} \%$ catalyst, determined by GC-FID. ${ }^{b} 5 \mathrm{~mol} \%$ catalyst loading. ${ }^{c} 45 \%$ conversion. ${ }^{d} 95 \%$ conversion. ${ }^{e} 83 \%$ conversion.

temperature (Table 3). Here, catalysts of different reactivity and chemical nature were selected: $\mathrm{AuCl}_{3}, \mathrm{Ph}_{3} \mathrm{PAuNTf}_{2}, \mathbf{A}$, and $\mathbf{D} / \mathrm{AgSbF}_{6}$. Irrespective of the catalyst, the same reactivity order for the three allenols was found: $\mathbf{1 a}$ is the most reactive one, followed by 1c, whereas $\mathbf{1 b}$ displays the lowest reactivity. In the latter case, $\mathrm{AuCl}_{3}$ and $\mathbf{D} / \mathrm{AgSbF}_{6}$ afforded incomplete conversion after $24 \mathrm{~h}$ at room temperature. Thus, compared to simple non-fluorinated allenes, introduction of a trifluoromethyl substituent causes a strong reactivity decrease. ${ }^{12}$ A consistent reactivity profile for the different gold catalysts was also observed. Catalyst $\mathbf{A}$ is the most active one, followed by $\mathrm{Ph}_{3} \mathrm{PAuNTf}_{2}$ (entries 2 \& 3), whereas $\mathrm{AuCl}_{3}$ (entry 1) and $\mathbf{D} / \mathrm{AgSbF}_{6}$ (entry 4) are less reactive.

Previously, it was demonstrated that gold catalysts in ionic liquids are stable to water, air and organic solvents and thus can be recycled after extraction of the product. ${ }^{9}$ This technique can also be applied to trifluoromethylated allenols, as shown exemplarily for substrate $\mathbf{1 a}$ (Table 4). The dihydrofuran $\mathbf{2 a}$ was isolated by extraction with pentane in good yields ${ }^{13}$ over five runs, and no loss of the catalytic activity was observed.

\section{Mechanistic studies}

To improve the mechanistic understanding of gold-catalyzed transformations in ionic liquids and in organic solvents, several experiments were carried out. First, in order to gather information about the solubility of trifluoromethylated allenes in ionic liquids, we examined an ultrasonicated mixture of 
Table 4 Recycling of the catalyst ${ }^{a}$

\begin{tabular}{lll}
\hline Run & Time $[\mathrm{min}]$ & Yield $^{b}[\%]$ \\
\hline 1 & 15 & 88 \\
2 & 15 & 90 \\
3 & 15 & 91 \\
4 & 15 & 88 \\
5 & 15 & 81
\end{tabular}

${ }^{a}$ Reaction conditions: allenol $\mathbf{1 a}+$ catalyst $\mathbf{A}(1 \mathrm{~mol} \%)$ in $[\mathrm{BMIM}]\left[\mathrm{PF}_{6}\right]$ at room temperature; product extraction with pentane. ${ }^{b}$ Isolated yield.

allenol 1a in [BMIM] $\left[\mathrm{PF}_{6}\right]$ under a light microscope. Droplets of the allene with diameters in the micrometer range were detected, which proves the presence of a heterogeneous twophasic system where phase transfer processes may be important for the overall rate of the reactions (ESI, Fig. SI1). Accordingly, the gold-catalyzed cyclization should be faster if the droplets are smaller. Indeed, we found an accelerating effect when the reaction was performed under ultrasonic conditions (Table SI 1 ).

Another important question is the nature of the active gold catalyst species in an ionic liquid. Previous studies revealed a stabilizing effect of the $\mathrm{IL}^{9,14}$ and the formation of gold nanoparticles. ${ }^{14}$ In order to investigate whether the stabilization can be attributed to the formation of gold-NHC complexes, we used $[\mathrm{BMMIM}]\left[\mathrm{PF}_{6}\right]$ which, compared to $[\mathrm{BMIM}]\left[\mathrm{PF}_{6}\right]$, has an additional methyl substituent in 2-position and cannot form an N-heterocyclic carbene. Moreover, we applied the goldNHC complexes $\mathbf{E}$ and $\mathbf{F}^{15}$ to the cyclization (Table 5).

Both ILs were used at $60{ }^{\circ} \mathrm{C}$ to maintain a sufficiently low viscosity (Table 5). It turned out that there is virtually no reac-

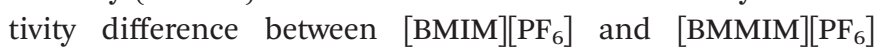
(entries 1 vs. $2 ; 3$ vs. $4 ; 5$ vs. 6). In all cases, a rapid cyclization

Table 5 Cycloisomerization of $\alpha$-hydroxyallene 1a to dihydrofuran 2a with different gold catalysts and ILs ${ }^{a}$
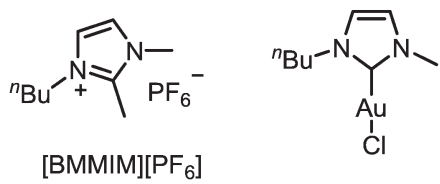

E

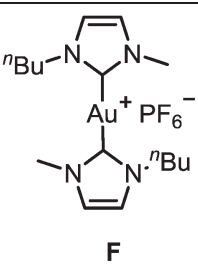

$\mathbf{F}$

\begin{tabular}{llllll}
\hline Entry & {$[\mathrm{Au}]^{a}$} & $\mathrm{IL}$ & $T\left[{ }^{\circ} \mathrm{C}\right]$ & Time & Conv. $^{b}[\%]$ \\
\hline 1 & $\mathrm{AuCl}_{3}$ & {$[\mathrm{BMIM}]\left[\mathrm{PF}_{6}\right]$} & 60 & $15 \mathrm{~min}$ & 100 \\
2 & $\mathrm{AuCl}_{3}$ & {$[\mathrm{BMMIM}]\left[\mathrm{PF}_{6}\right]$} & 60 & $20 \mathrm{~min}$ & 100 \\
3 & $\mathbf{A}$ & {$[\mathrm{BMIM}]\left[\mathrm{PF}_{6}\right]$} & 60 & $5 \mathrm{~min}$ & 100 \\
4 & $\mathbf{A}$ & {$[\mathrm{BMMIM}]\left[\mathrm{PF}_{6}\right]$} & 60 & $5 \mathrm{~min}$ & 100 \\
5 & $\mathrm{Ph}_{3} \mathrm{PAuNTf}_{2}$ & {$[\mathrm{BMIM}]\left[\mathrm{PF}_{6}\right]$} & 60 & $15 \mathrm{~min}$ & 100 \\
6 & $\mathrm{Ph}_{3} \mathrm{PAuNTf}_{2}$ & {$[\mathrm{BMMIM}]\left[\mathrm{PF}_{6}\right]$} & 60 & $20 \mathrm{~min}$ & 100 \\
7 & $\mathbf{E} / \mathrm{AgSbF}_{6}$ & {$[\mathrm{BMIM}]\left[\mathrm{PF}_{6}\right]$} & 25 & $4 \mathrm{~h}$ & 100 \\
8 & $\mathbf{E}$ & {$[\mathrm{BMIM}]\left[\mathrm{PF}_{6}\right]$} & 25 & $24 \mathrm{~h}$ & 0 \\
9 & $\mathbf{F}$ & {$[\mathrm{BMIM}]\left[\mathrm{PF}_{6}\right]$} & 25 & $24 \mathrm{~h}$ & 0
\end{tabular}

${ }^{a}$ Catalyst loading: 5 mol\% (entries 1 \& 2); 2 mol\% (entries 3-9). ${ }^{b}$ Determined by GC-FID. took place within 5-20 min. Thus, the formation of gold-NHC complexes is not required for the catalytic activity, but it may contribute to the stability of the catalyst in ILs. Remarkably, complex $\mathbf{E}$ showed a good catalytic activity after activation with $\mathrm{AgSbF}_{6}$ (entries 7 and 8), while the ionic dimer $\mathbf{F}$ is completely unreactive (entry 9). Hence, formation of dimeric gold-NHC complexes of the type $\mathbf{F}$ may be a pathway leading to deactivation of the gold catalyst.

The mechanism of the gold-catalyzed endo-selective cycloisomerization of $\alpha$-functionalized allenes has been studied extensively, leading to the catalytic cycle shown in Scheme $2{ }^{7,16}$ In the first step the $\pi$-complex II is generated by coordination of the catalytically active gold species to a C-Cdouble bond of allene $\mathbf{I}$. The subsequent intramolecular attack of the nucleophile leads to the $\sigma$-gold species III. Finally, protodeauration affords the product IV and regenerates the gold catalyst. Due to the observation that the cycloisomerization of simple $\alpha$-hydroxyallenes is accelerated in the presence of external proton donors, it is assumed that the protodeauration is the rate determining step of this reaction.

In a recent seminal contribution, Wang, Hammond, and $\mathrm{Xu}^{17}$ have examined the influence of electronically different ligands on the rate of gold-catalyzed transformations. Whereas the activation of an unsaturated substrate $(e . g ., \mathbf{I} \rightarrow$ II) can be accelerated by electron-deficient ligands, the rate of the protodeauration of a $\sigma$-vinylgold species $(e . g$., III $\rightarrow$ IV) can be increased by electron-rich ligands. Thus, the opposing electron demand of the individual reactions can be used to determine the rate-determining step of the catalytic cycle. We first applied Hammond's method to the gold-catalyzed cycloisomerization of the exemplary non-fluorinated $\alpha$-functionalized allenes $\mathbf{3 a} / \mathbf{b}$ which afford the heterocycles $\mathbf{4 a} / \mathbf{b}$ (Scheme 3).

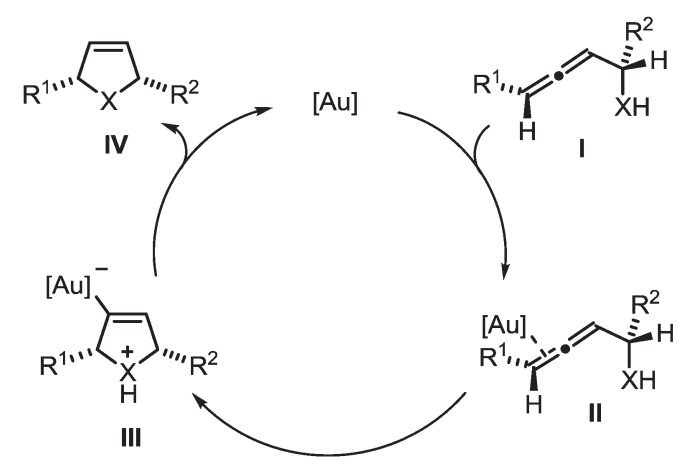

Scheme 2 Proposed mechanism of the gold-catalyzed cycloisomerization of $\alpha$-functionalized allenes $(X=N R, O, S)$.

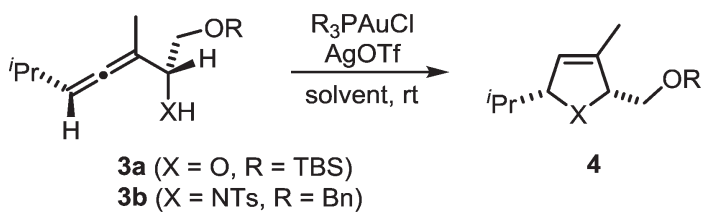

Scheme 3 Gold-catalyzed cycloisomerization of allenes $3 a / b$. 
Six phosphine- or phosphite-gold complexes were used for this kinetic study; the ligands exhibit decreasing electron-donating ability in the following order: $\mathbf{B}>$ $\left(4-\mathrm{MeOC}_{6} \mathrm{H}_{4}\right)_{3} \mathrm{PAuCl}>\left(4-\mathrm{MeC}_{6} \mathrm{H}_{4}\right)_{3} \mathrm{PAuCl}>\mathrm{Ph}_{3} \mathrm{PAuCl}>$ $\left(4-\mathrm{CF}_{3} \mathrm{C}_{6} \mathrm{H}_{4}\right)_{3} \mathrm{PAuCl}>$ D. The chlorocomplexes were activated with equimolar amounts of AgOTf. Different solvents and catalyst loadings were tested to find optimal reaction conditions. Reaction times between 1 and $3 \mathrm{~h}$ were required in order to gather a sufficient number of samples which were analyzed by gas chromatography. The results obtained for $\alpha$-hydroxyallene 3a are shown in Fig. 1. They clearly show that the rate of the cyclization is rising with increasing electron-donating properties of the ligand. In the context of Hammond's results, this indicates that the protodeauration of the $\sigma$-vinylgold species III is the rate-determining step of the catalytic cycle.

The corresponding kinetic study with $\alpha$-aminoallene $\mathbf{3 b}$ was carried out with four phosphinegold complexes (Fig. 2). Again, electron-rich ligands lead to rapid cyclizations. Thus, also for aminoallene $\mathbf{3} \mathbf{b}$, the protodeauration is the rate-determining step.

Pushing the limits of the accelerating effect of electron-rich phosphine ligands is possible by changing the number and position of electron-releasing groups. This could be demonstrated for the cycloisomerization of allenol 3a with methoxysubstituted phosphinegold complexes (Fig. 3). It turned out that the accelerating effect of the methoxy group in 2-position is stronger than in 4-position. Accordingly, the catalyst formed from $\left[2,4,6-(\mathrm{MeO})_{3} \mathrm{C}_{6} \mathrm{H}_{2}\right]_{3} \mathrm{PAuCl}$ and AgOTf gave by far the fastest cyclization.

Recently, Hammond and co-workers demonstrated that additives with good hydrogen-bond acceptor ability can increase the rate of gold-catalyzed reactions if the protodeauration is the rate-limiting step. ${ }^{18}$ We examined this effect for the goldcatalyzed cycloisomerization of $\mathbf{3 a}$ with $\mathrm{Ph}_{3} \mathrm{PAuCl} / \mathrm{AgOTf}$ in the presence of $\mathrm{Bu}_{4} \mathrm{NOTf}$ or pyridin- $N$-oxide (Fig. 4). As expected, both additives accelerate the conversion of allene 3a. This result confirms once more the protodeauration as rate-determining step.

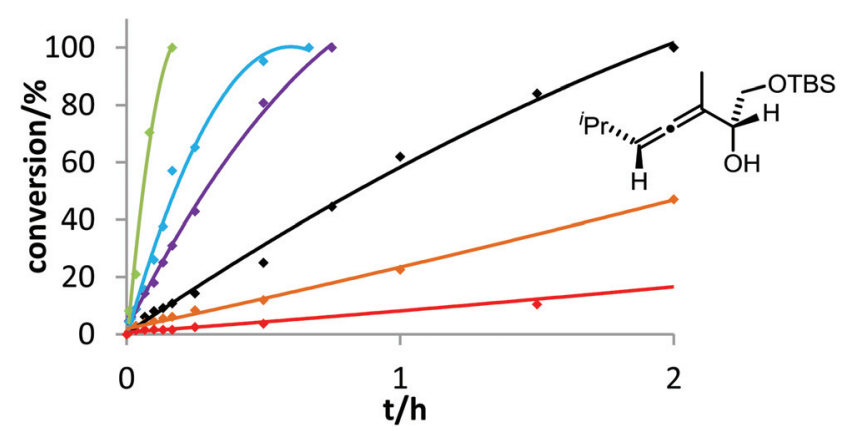

Fig. 1 Ligand effect on the gold-catalyzed cycloisomerization of $3 a$. $4 \mathrm{~mol} \%[\mathrm{Au}]$ and $4 \mathrm{~mol} \% \mathrm{AgOTf}$ were used in DMF at room temperature. Decreasing reactivity was observed in the following order: $\mathrm{B}$ (green) > $\left(4-\mathrm{MeOC}_{6} \mathrm{H}_{4}\right)_{3} \mathrm{PAuCl}$ (blue) $>\left(4-\mathrm{MeC}_{6} \mathrm{H}_{4}\right)_{3} \mathrm{PAuCl}$ (violet) $>\mathrm{Ph}_{3} \mathrm{PAuCl}$ (black) $>\left(4-\mathrm{CF}_{3} \mathrm{C}_{6} \mathrm{H}_{4}\right)_{3} \mathrm{PAuCl}$ (orange) $>\mathrm{D}$ (red).

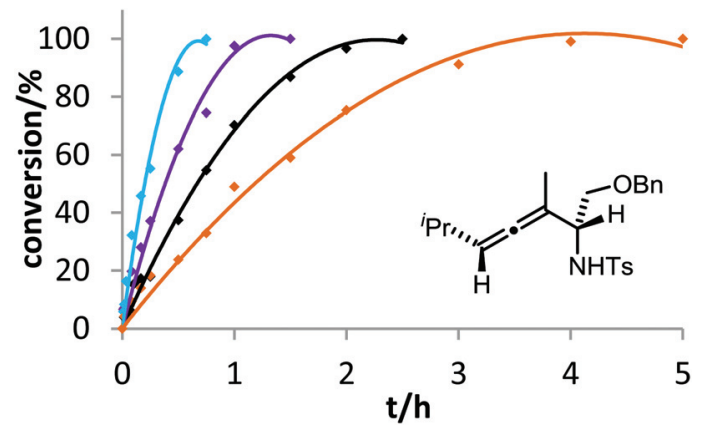

Fig. 2 Ligand effect on the gold-catalyzed cycloisomerization of $3 b$. $2 \mathrm{~mol} \%[\mathrm{Au}]$ and $2 \mathrm{~mol} \%$ AgOTf were used in THF at room temperature. Decreasing reactivity was observed in the following order: $\left(4-\mathrm{MeOC}_{6} \mathrm{H}_{4}\right)_{3} \mathrm{PAuCl}$ (blue) $>\left(4-\mathrm{MeC}_{6} \mathrm{H}_{4}\right)_{3} \mathrm{PAuCl}$ (violet) $>\mathrm{Ph}_{3} \mathrm{PAuCl}$ (black) $>\left(4-\mathrm{CF}_{3} \mathrm{C}_{6} \mathrm{H}_{4}\right)_{3} \mathrm{PAuCl}$ (orange).

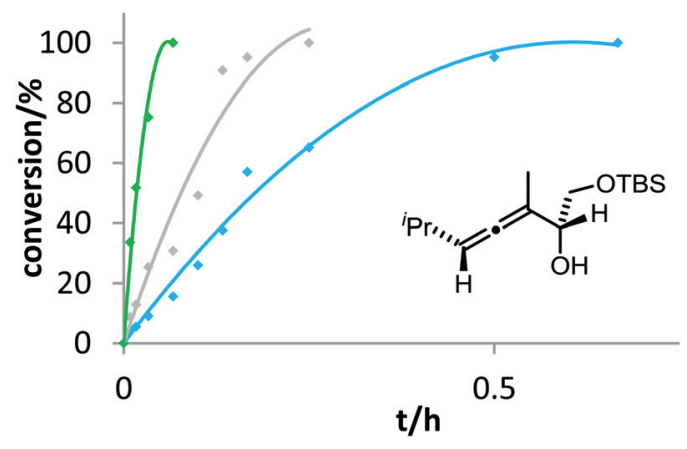

Fig. 3 Effect of the number and position of electron-releasing substituents on the gold-catalyzed cycloisomerization of 3a. $4 \mathrm{~mol} \%$ [Au] and $4 \mathrm{~mol} \%$ AgOTf were used in DMF at room temperature. Decreasing reactivity was observed in the following order: $\left[2,4,6-(\mathrm{MeO})_{3} \mathrm{C}_{6} \mathrm{H}_{2}\right]_{3} \mathrm{PAuCl}$ (green) $>\left(2-\mathrm{MeOC}_{6} \mathrm{H}_{4}\right)_{3} \mathrm{PAuCl}$ (grey) $>\left(4-\mathrm{MeOC}_{6} \mathrm{H}_{4}\right)_{3} \mathrm{PAuCl}$ (blue).

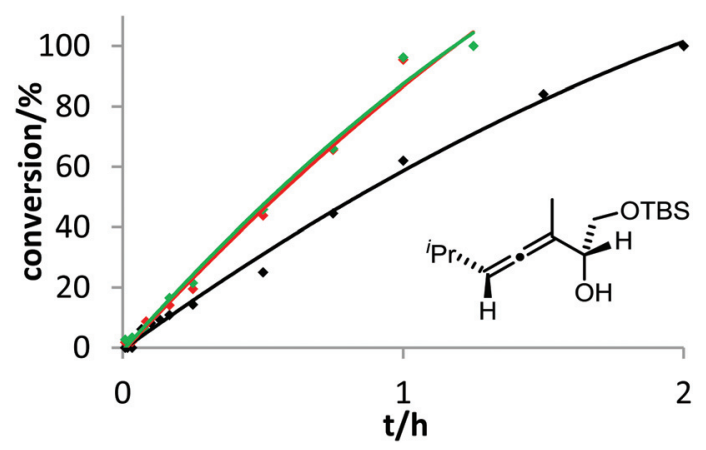

Fig. 4 Effect of additives on the gold-catalyzed cycloisomerization of 3a. $4 \mathrm{~mol} \% \mathrm{Ph}_{3} \mathrm{PAuCl}, 4 \mathrm{~mol} \% \mathrm{AgOTf}, 5 \mathrm{~mol} \%$ additive were used in DMF at room temperature. Decreasing reactivity was observed in the following order: $\mathrm{Ph}_{3} \mathrm{PAuCl}+$ pyridin- $\mathrm{N}$-oxide (green) $\approx \mathrm{Ph}_{3} \mathrm{PAuCl}+\mathrm{Bu}_{4} \mathrm{NOTf}$ (red) $>\mathrm{Ph}_{3} \mathrm{PAuCl}$ (black).

After demonstrating the viability of Hammond's method for the gold-catalyzed cyclization of allenes $3 \mathbf{a} / \mathbf{b}$, we extended our kinetic study to the trifluoromethylated counterparts $\mathbf{1 a - c .}$ As already mentioned above, introduction of the electron-with- 


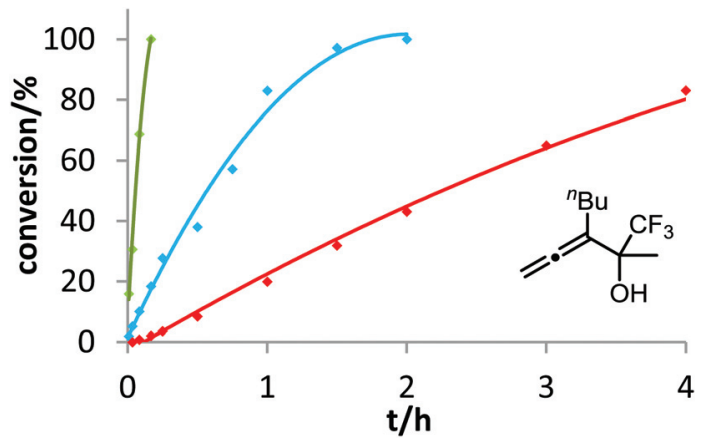

Fig. 5 Ligand effect on the gold-catalyzed cycloisomerization of 1 a. $5 \mathrm{~mol} \%[\mathrm{Au}]$ and $5 \mathrm{~mol} \%$ AgOTf were used in THF at room temperature. Decreasing reactivity was observed in the following order: $\mathbf{B}$ (green) > $\left(4-\mathrm{MeOC}_{6} \mathrm{H}_{4}\right)_{3} \mathrm{PAuCl}$ (blue) > D (red).

drawing $\mathrm{CF}_{3}$ group causes a strong decrease of reactivity in the gold-catalyzed cyclization. ${ }^{12}$ Is this effect accompanied by a change of the rate-determining step? As can be seen in Fig. 5 and 6 , this is not the case of allenols $\mathbf{1 a}$ and $\mathbf{1 b}$. For both substrates, the electron-rich gold catalysts $\mathbf{B}$ and $\left(4-\mathrm{MeOC}_{6} \mathrm{H}_{4}\right)_{3} \mathrm{PAuCl}$ gave faster reactions than the electronpoor phosphite-gold complex $\mathbf{D}$. Thus, also for these allenes the protodeauration is rate-limiting.

In contrast to the previous substrates, allenol $1 \mathrm{c}$ bearing a trifluoromethyl group at C-5 shows a different kinetic behavior (Fig. 7). Here, the electron-deficient phosphite-gold catalyst $\mathbf{D}$ induces the fastest reaction, the electron-rich phosphine-gold complex B the slowest. According to Hammond's investigations, this indicates that the activation of the allene with formation of $\pi$-complex II is the rate-determining step of the catalytic cycle.

With our kinetic study, we could show for the first time that the rate-determining step of a gold-catalyzed transformation can be changed by variation of the electronic properties of the substrate. It appears that in the case of allenol 1c, the electronwithdrawing effect of the $\mathrm{CF}_{3}$ group at $\mathrm{C}-5$ causes a strong decrease of electron density at the adjacent $\mathrm{C}-\mathrm{C}$ double bond.

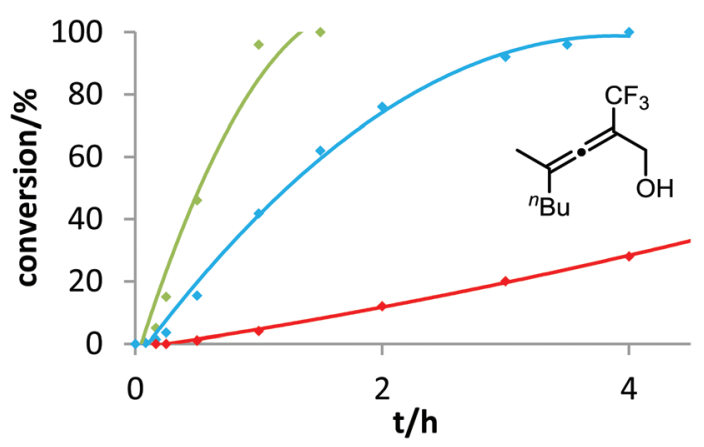

Fig. 6 Ligand effect on the gold-catalyzed cycloisomerization of $1 \mathbf{b}$. $2 \mathrm{~mol} \%[\mathrm{Au}]$ and $2 \mathrm{~mol} \%$ AgOTf were used in DCM at room temperature. Decreasing reactivity was observed in the following order: $\mathbf{B}$ (green) > $\left(4-\mathrm{MeOC}_{6} \mathrm{H}_{4}\right)_{3} \mathrm{PAuCl}$ (blue) $>$ D (red).

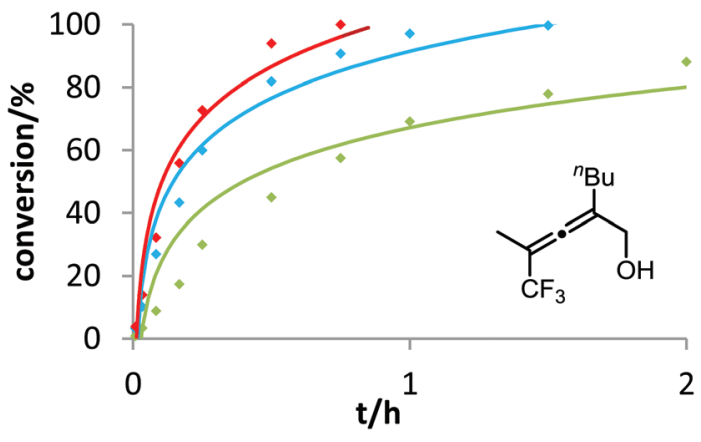

Fig. 7 Ligand effect on the gold-catalyzed cycloisomerization of 1c. $3 \mathrm{~mol} \%[\mathrm{Au}]$ and $3 \mathrm{~mol} \% \mathrm{AgOTf}$ were used in toluene at room temperature. Decreasing reactivity was observed in the following order: $\mathbf{D}($ red) $>$ $\left(4-\mathrm{MeOC}_{6} \mathrm{H}_{4}\right)_{3} \mathrm{PAuCl}$ (blue) > $\mathrm{B}$ (green).

As a consequence, formation of $\pi$-complex II is slowed down to such an extent that this step becomes rate-limiting. Unfortunately, due to the heterogeneous nature of the reaction mixture in ILs (see above), it is not possible to conduct these kinetic studies in ionic liquids. In the future, we will include steric effects, ${ }^{19}$ as well as the influence of the counterion of cationic gold catalysts, ${ }^{20}$ in these mechanistic studies.

\section{Conclusions}

In this study, we have demonstrated that trifluoromethyl-substituted $\alpha$-allenols can be cyclized to the corresponding 2,5dihydrofurans in the presence of neutral or cationic gold catalysts. When ionic liquids (in particular $[\mathrm{BMIM}]\left[\mathrm{PF}_{6}\right]$ ) are used as reaction medium, the sustainability of these transformations is improved since a recycling of the gold catalyst becomes possible. Distinct reactivity differences between the allenols 1a-c and the gold catalysts were noted. The allenes form droplets in ionic liquids generating a heterogeneous twophasic system. As a result, diffusion and interface exchange processes may have a strong influence on the rate of the reaction. The formation of gold-NHC complexes is not required for the catalytic activity, but it may contribute to the stability of the catalyst in ILs. Extensive kinetic studies in organic solvents using phosphine- or phosphite-gold catalysts with different electronic properties allowed to identify the protodeauration of $\sigma$-gold-species III as rate-determining step of the catalytic cycle for fluorinated allenols $\mathbf{1} \mathbf{a} / \mathbf{b}$, as well as for the non-fluorinated substrates $3 \mathbf{a} / \mathbf{b}$. In contrast, activation of the allene with formation of $\pi$-complex II is the rate-limiting step for substrate 1c. This mechanistic change (which has been determined for the first time for a gold-catalyzed transformation) is probably caused by the electron-withdrawing effect of the $\mathrm{CF}_{3}$ group at $\mathrm{C}-5$ which strongly decreases the electron density of the adjacent $\mathrm{C}-\mathrm{C}$ double bond. Our study underlines the importance of sustainable reaction conditions, as well as, mechanistic investigations for the improvement of catalytic processes. Further work along these lines is in progress. 


\section{Notes and references}

1 (a) W. R. Dolbier Jr., J. Fluorine Chem., 2005, 126, 157; (b) P. Kirsch, Modern Fluoroorganic Chemistry: Synthesis, Reactivity, Applications, Wiley-VCH, Weinheim, 2013.

2 (a) D. O'Hagan, Chem. Soc. Rev., 2008, 37, 308; (b) T. Liang, C. N. Neumann and T. Ritter, Angew. Chem., Int. Ed., 2013, 52, 8214; (c) M. F. Kuehnel, D. Lentz and T. Braun, Angew. Chem., Int. Ed., 2013, 52, 3328; (d) P. R. Savoie and J. T. Welch, Chem. Rev., 2015, 115, 1130.

3 (a) H.-J. Böhm, D. Banner, S. Bendels, M. Kansy, B. Kuhn, K. Müller, U. Obst-Sander and M. Stahl, ChemBioChem, 2004, 5, 637; (b) W. K. Hagmann, J. Med. Chem., 2008, 51, 4359; (c) D. O’Hagan, J. Fluorine Chem., 2010, 131, 1071; (d) J. Wang, M. Sánchez-Roselló, J. L. Aceña, C. del Pozo, A. E. Sorochinsky, S. Fustero, V. A. Soloshonok and H. Liu, Chem. Rev., 2014, 114, 2432.

4 (a) A. Corma, A. Leyva-Pérez and M. J. Sabater, Chem. Rev., 2011, 111, 1657; (b) G. Liu, Org. Biomol. Chem., 2012, 10, 6243.

5 (a) M. Schuler, F. Silva, C. Bobbio, A. Tessier and V. Gouverneur, Angew. Chem., Int. Ed., 2008, 47, 7927; (b) W. Wang, J. Jasinski, G. B. Hammond and B. Xu, Angew. Chem., Int. Ed., 2010, 49, 7247; (c) J. Qian, Y. Liu, J. Zhu, B. Jiang and Z. Xu, Org. Lett., 2011, 13, 4220; (d) Y. Liu, J. Zhu, J. Qian and Z. Xu, J. Org. Chem., 2012, 77, 5411; (e) Z. Jin, R. S. Hidinger, B. Xu and G. B. Hammond, J. Org. Chem., 2012, 77, 7725; (f) S. Li, Z. Li, Y. Yuan, Y. Li, L. Zhang and Y. Wu, Chem. - Eur. J., 2013, 19, 1496; $(g)$ A. Arcadi, E. Pietropaolo, A. Alvino and V. Michelet, Org. Lett., 2013, 15, 2766; (h) A. Arcadi, E. Pietropaolo, A. Alvino and V. Michelet, Beilstein J. Org. Chem., 2014, 10, 449; (i) Y. Jeong, B.-I. Kim, J. K. Lee and J.-S. Ryu, J. Org. Chem., 2014, 79, 6444.

6 (a) R. Surmont, G. Verniest and N. De Kimpe, Org. Lett., 2009, 11, 2920; (b) Y. Li, K. A. Wheeler and R. Dembinski, Adv. Synth. Catal., 2010, 352, 2761; (c) Y. Li, K. A. Wheeler and R. Dembinski, Eur. J. Org. Chem., 2011, 2767; (d) Y. Li, K. A. Wheeler and R. Dembinski, Org. Biomol. Chem., 2012, 10, 2395; (e) S. Li, Z. Li, Y. Yuan, D. Peng, Y. Li, L. Zhang and Y. Wu, Org. Lett., 2012, 14, 1130; (f) S. Fustero, I. Ibáñez, P. Barrio, M. A. Maestro and S. Catalán, Org. Lett., 2013, 15, 832.

7 (a) N. Krause, V. Belting, C. Deutsch, J. Erdsack, H.-T. Fan, B. Gockel, A. Hoffmann-Röder, N. Morita and F. Volz, Pure
Appl. Chem., 2008, 80, 1063; (b) N. Krause, Ö. Aksin-Artok, V. Breker, C. Deutsch, B. Gockel, M. Poonoth, Y. Sawama, Y. Sawama, T. Sun and C. Winter, Pure Appl. Chem., 2010, 82, 1529; (c) N. Krause, Ö. Aksin-Artok, M. Asikainen, V. Breker, C. Deutsch, J. Erdsack, H.-T. Fan, B. Gockel, S. Minkler, M. Poonoth, Y. Sawama, Y. Sawama, T. Sun, F. Volz and C. Winter, J. Organomet. Chem., 2012, 704, 1; (d) B. Wagner, K. Belger, S. Minkler, V. Belting and N. Krause, Pure Appl. Chem., 2016, 88, 391.

8 (a) S. R. K. Minkler, B. H. Lipshutz and N. Krause, Angew. Chem., Int. Ed., 2011, 50, 7820; (b) S. R. K. Minkler, N. A. Isley, D. J. Lippincott, N. Krause and B. H. Lipshutz, Org. Lett., 2014, 16, 724; (c) S. Handa, D. J. Lippincott, D. H. Aue and B. H. Lipshutz, Angew. Chem., Int. Ed., 2014, 53, 10658; (d) L. Lempke, A. Ernst, F. Kahl, R. Weberskirch and N. Krause, Adv. Synth. Catal., 2016, 358, 1491; (e) K. Belger and N. Krause, Eur. J. Org. Chem., 2015, 220; (f) K. Belger and N. Krause, Org. Biomol. Chem., 2015, 13, 8556.

9 (a) Ö. Aksin and N. Krause, Adv. Synth. Catal., 2008, 350, 1106; (b) L. Lempke, T. Fischer, J. Bell, W. Kraus, K. Rurack and N. Krause, Org. Biomol. Chem., 2015, 13, 3787.

$10(a)$ N. Krause, M. Laux and A. Hoffmann-Röder, Tetrahedron Lett., 2000, 41, 9613; (b) A. Hoffmann-Röder and N. Krause, Org. Lett., 2001, 3, 2537.

11 S. M. Kim, J. H. Park and Y. K. Chung, Chem. Commun., 2011, 47, 6719.

12 Under the conditions of Table 3 , the corresponding nonfluorinated allenols require only $5-10 \mathrm{~min}$ at room temperature for full conversion to the 2,5-dihydrofuran.

13 Isolated yields of dihydrofurans $2 \mathbf{b} / \mathbf{c}$ under the conditions of Table 4: 91\% (2b), 90\% (2c).

14 A. Corma, I. Domínguez, T. Ródenas and M. J. Sabater, J. Catal., 2008, 259, 26.

15 L. Messori, L. Marchetti, L. Massai, F. Scaletti, A. Guerri, I. Landini, S. Nobili, G. Perrone, E. Mini, P. Leoni, M. Pasquali and C. Gabbiani, Inorg. Chem., 2014, 53, 2396.

16 N. Krause and C. Winter, Chem. Rev., 2011, 111, 1994.

17 W. Wang, G. B. Hammond and B. Xu, J. Am. Chem. Soc., 2012, 134, 5697.

18 W. Wang, M. Kumar, G. B. Hammond and B. Xu, Org. Lett., 2014, 16, 636.

19 R. E. Ebule, D. Malhotra, G. B. Hammond and B. Xu, Adv. Synth. Catal., 2016, 358, 1478.

20 M. Jia and M. Bandini, ACS Catal., 2015, 5, 1638. 